\title{
Article
}

\section{The Netherlands Twin Register: Longitudinal Research Based on Twin and Twin-Family Designs}

\author{
Lannie Ligthart ${ }^{1,2}$, Catharina E.M. van Beijsterveldt ${ }^{1,2}$, Sofieke T. Kevenaar ${ }^{1,2}$, Eveline de Zeeuw ${ }^{1,2}$, Elsje van Bergen ${ }^{1,2}$, \\ Susanne Bruins ${ }^{1,2}$, René Pool ${ }^{1,2}$, Quinta Helmer ${ }^{1,2}$, Jenny van Dongen ${ }^{1,2}$, Jouke-Jan Hottenga ${ }^{1,2}$, Dennis van't Ent ${ }^{1,2}$, \\ Conor V. Dolan ${ }^{1,2}$, Gareth E. Davies ${ }^{3}$, Erik A. Ehli ${ }^{3}$, Meike Bartels ${ }^{1,2, \star}$, Gonneke Willemsen ${ }^{1,2, \star}$, Eco J.C. de Geus ${ }^{1,2, \star}$ and \\ Dorret I. Boomsma ${ }^{1,2, *}$ \\ ${ }^{1}$ Department of Biological Psychology, Vrije Universiteit Amsterdam, Amsterdam, the Netherlands, ${ }^{2}$ Amsterdam Public Health Research Institute, Amsterdam, \\ the Netherlands and ${ }^{3}$ Avera Institute for Human Genetics, Sioux Falls, SD, USA
}

\begin{abstract}
The Netherlands Twin Register (NTR) is a national register in which twins, multiples and their parents, siblings, spouses and other family members participate. Here we describe the NTR resources that were created from more than 30 years of data collections; the development and maintenance of the newly developed database systems, and the possibilities these resources create for future research. Since the early 1980 s, the NTR has enrolled around 120,000 twins and a roughly equal number of their relatives. The majority of twin families have participated in survey studies, and subsamples took part in biomaterial collection (e.g., DNA) and dedicated projects, for example, for neuropsychological, biomarker and behavioral traits. The recruitment into the NTR is all inclusive without any restrictions on enrollment. These resources - the longitudinal phenotyping, the extended pedigree structures and the multigeneration genotyping — allow for future twin-family research that will contribute to gene discovery, causality modeling, and studies of genetic and cultural inheritance.
\end{abstract}

Keywords: Twins; multigeneration pedigree; zygosity; biobank; endophenotyping; longitudinal phenotyping

(Received 30 May 2019; accepted 6 July 2019; First Published online 31 October 2019)

For more than three decades, the Netherlands Twin Register (NTR) has invited twins and their family members to take part in research studies of development, health and behavior. The recruitment has mostly included two-generation extended families. The NTR has created a rich resource of data to assess genetic and nongenetic (cultural) transmission, and to contribute to gene-finding studies for complex human phenotypes. In this article we describe, by necessity in broad strokes, our recruitment procedures, the number of participants, the phenotyping through surveys and other data collection methods, and the collection of genotype and other omics data. We also summarize how we are constructing a data warehouse to archive the numerous datasets and make them optimally accessible for researchers, even when data were collected two or more decades ago.

This paper is incremental in a series of earlier papers on NTR resources (Bartels et al., 2007; Boomsma et al., 1992, 2002, 2006, 2008; Hoekstra et al., 2004; van Beijsterveldt et al., 2013; Willemsen et al., 2010, 2013), and aims to give an overview

Author for correspondence: Lannie Ligthart, Email: rsl.ligthart@vu.nl

* Management Team Netherlands Twin Register.

Cite this article: Ligthart L, van Beijsterveldt CEM, Kevenaar ST, de Zeeuw E, van Bergen E, Bruins S, Pool R, Helmer Q, van Dongen J, Hottenga J-J, van't Ent D, Dolan CV, Davies GE, Ehli EA, Bartels M, Willemsen G, de Geus EJC, and Boomsma DI. (2019) The Netherlands Twin Register: Longitudinal Research Based on Twin and Twin-Family Designs. Twin Research and Human Genetics 22: 623-636, https://doi.org/10.1017/thg.2019.93 from the first twin-family studies in the 1980s, via the formal establishment of the Young and Adult NTR and the NTR biobank to our latest projects. Participants who register with NTR are invited for research projects entailing surveys, interviews and other phenotyping studies, biomarker and omics research projects, and are also asked for permission for record linkage. Since the first twin-family studies were carried out for cardiovascular risk factors in the early 1980s on several hundreds of participants, data have been collected on tens of thousands of children and adults, and across a wide range of phenotypes.

\section{Recruitment}

Starting around 1986, NTR systematically started to approach parents to register their newborn twins in the Young NTR (YNTR) with the help of a commercial 'birth felicitation' service. Additional recruitment of newborn twins and triplets and their parents is done with the support of the Dutch Society of Parents of Multiples (Nederlandse Vereniging van Ouders van Meerlingen: NVOM; https://www.nvom.nl). After parents return an informed consent form, the family is registered with the NTR and mothers receive a first survey with items on pre- and perinatal variables. When the twins are 2 years of age, a survey on growth, health, developmental and motor milestones is sent. At ages 3, 5, 7, 9/10 and 12 years, both parents receive additional surveys addressing a broader set of behavioral and health-related

(C) The Author(s) 2019. This is an Open Access article, distributed under the terms of the Creative Commons Attribution licence (http://creativecommons.org/licenses/by/4.0/), which permits unrestricted re-use, distribution, and reproduction in any medium, provided the original work is properly cited 
Table 1. Number of registered participants as of 2019 by role and age group

\begin{tabular}{lcccc} 
& $0-11$ years & $12-17$ years & $18+$ & Total \\
\hline Multiples & 27,474 & 20,949 & 73,734 & 122,157 \\
\hline Siblings & 628 & 2338 & 11,938 & 14,904 \\
\hline Parents & 0 & 0 & 114,278 & 114,278 \\
\hline Spouses & 0 & 0 & 2616 & 2616 \\
\hline Offspring & 280 & 28 & 778 & 1086 \\
\hline Other & 1 & 4 & 683 & 688 \\
\hline Total & 28,383 & 23,319 & 204,027 & $255,729^{a}$ \\
\hline
\end{tabular}

${ }^{\mathrm{a} D u e}$ to unknown age, 56 participants are not listed in this table.

traits. At ages 7, 9/10 and 12 years, we also ask parents for permission to approach the twins' teachers. At that same moment, we ask if there are any additional siblings in the family who are in elementary school and whose teachers may be approached. From age 14 onward, adolescent twins and their siblings are invited to provide self-reports (after their parents give permission), largely substituting parental for self-report form this age onward. Once they become adults, the YNTR twins can opt to join the Adult NTR (ANTR).

Apart from the YNTR influx, ANTR twins have been recruited through city councils, starting in 1985 with smaller numbers of twin families in and around Amsterdam. In 1990-1993, a nationwide appeal to city councils for permission to approach adolescent and young adult twins and multiples and their parents was successful and created the basis for the ANTR, with the first surveys collected in 1991. Additional means of recruitment are the yearly NTR newsletter Twinfo, the NTR website and national events organized by, for example, the Dutch Twin Society. Surveys have been sent to ANTR participants about every 2-3 years since 1991. In total, 13 large-scale surveys have been collected. In contrast to the YNTR, where data collection is based on birth cohort and age, the ANTR data collection is independent of age and includes all adult participants.

As a result of the recruitment efforts described above, the NTR has registered about $52 \%$ of all Dutch twin-pairs born between 1987 and 2017, based on data from Statistics Netherlands (CBS; https://www.cbs.nl/nl-nl/nieuws/2016/39/minder-tweelingengeboren). Most of these twin-pairs were recruited shortly after birth. The birth cohorts between 1970 and 1981 are also well represented (29\%). For other birth cohorts, coverage is considerably lower due to lack of systematic recruitment.

\section{Number of Participants}

Using the twin-pair as the probands, recruitment in both ANTR and YTNR initially included parents, and in later years also siblings, spouses and offspring of twins. This has resulted in a database with roughly equal proportions of participants who are and who are not twins. Over the years, a total of 280,569 participants were registered at the NTR, 231,088 of whom are still contactable. The total group of participants includes 255,785 members of twin families and 24,784 participants contributing as a teacher of a child registered at the NTR. Table 1 provides information about the age distribution in twins, parents, siblings and other groups of participants. Until now, the NTR has collected phenotypic data on $70 \%$ of all registered twin-family participants (i.e., excluding teachers). This includes self-report data, survey data supplied by parents or teachers, and data collected in dedicated projects such as cardiovascular and magnetic resonance imaging (MRI) studies.
Table 2. Number of $M Z$ and $D Z$ twins by sex and age group

\begin{tabular}{lcccc} 
& $0-11$ years & $12-17$ years & $18+$ & Total \\
\hline MZ male & 2126 & 2402 & 8780 & 13,308 \\
\hline DZ male & 1972 & 2946 & 9540 & 14,458 \\
\hline MZ female & 2056 & 2544 & 11,974 & 16,574 \\
\hline DZ female & 1892 & 2642 & 9794 & 14,328 \\
\hline DZ opposite sex & 8908 & 6904 & 22,112 & 37,932 \\
\hline Total & 16,954 & 17,438 & 62,200 & $96,600^{\text {a }}$ \\
\hline
\end{tabular}

a Numbers represent individuals, not pairs, and only include twins, not higher order multiples. Zygosity is not known for all registered twins; however, in the case of an opposite sex pair, no survey or DNA information is needed to determine zygosity. Therefore, this group is relatively large compared to the other zygosity groups.

\section{Zygosity}

Most NTR surveys contain a standard series of items for zygosity assessment, addressing several aspects of physical resemblance and the degree to which the twins are confused by parents, other relatives and strangers. In YNTR and ANTR data, a series of discriminant analyses was performed to assess the accuracy of zygosity classification based on survey items, using information from blood group and DNA polymorphisms as the index of true zygosity. In the YNTR, the accuracy of classification at age 3 years and older was $97.2 \%$, based on a set of 10 questionnaire items. In the ANTR, where a set of eight items is used, the correspondence was $95.9 \%$. For more details on the zygosity classification, see the Appendix. Table 2 shows the numbers of monozygotic (MZ) and dizygotic (DZ) twins within the NTR, stratified by age and sex.

\section{YNTR and ANTR: Longitudinal Survey Collection}

Tables 3 and 4 summarize the numbers of twins and family members who have participated in YNTR and ANTR survey research as of April 2019. Separate columns indicate for how many participants the phenotypic data from the surveys were enriched by DNA collection and genomewide single nucleotide polymorphism (SNP) genotyping.

Longitudinal data collection by surveys began by paper and pencil and has now been replaced by online survey collection. The YNTR surveys focus on growth and physical development, wellbeing, health status and health behaviors, and behavioral and emotional problems as rated by parents and at ages 7 , $9 / 10$ and 12 years by teachers. Over time, surveys have been kept as similar as possible, relying on standardized inventories such as the Achenbach System of Empirically Based Assessment (ASEBA; Achenbach et al., 2017) which allows for multi-informant assessment at ages $1 \frac{1}{2}$ through $90+$ years (i.e., parents, teacher and self-assessment), and the Conners' Teacher Rating Scales-Revised for teachers (Conners et al., 1998b), the Conners' Parent Rating Scale-Revised (Conners et al., 1998a) for parents of young twins and the Conners' Adult ADHD Rating Scales for adults (Conners et al., 1999). New instruments have been added in recent years, e.g. the Child Behavior Questionnaire (CBQ; Rothbart et al., 2001), for assessment of behavioral control at age 5 by parents, and the Social Skills Rating System (SSRS; Gresham \& Elliott, 1990) for assessment of social competence at ages 7, 9 and 12 by teachers and wellbeing (Cantril Ladder; Cantril, 1965). Other topics addressed in the YNTR surveys include the use 
Table 3. Numbers of available surveys per type of rater for young multiples and siblings (YNTR)

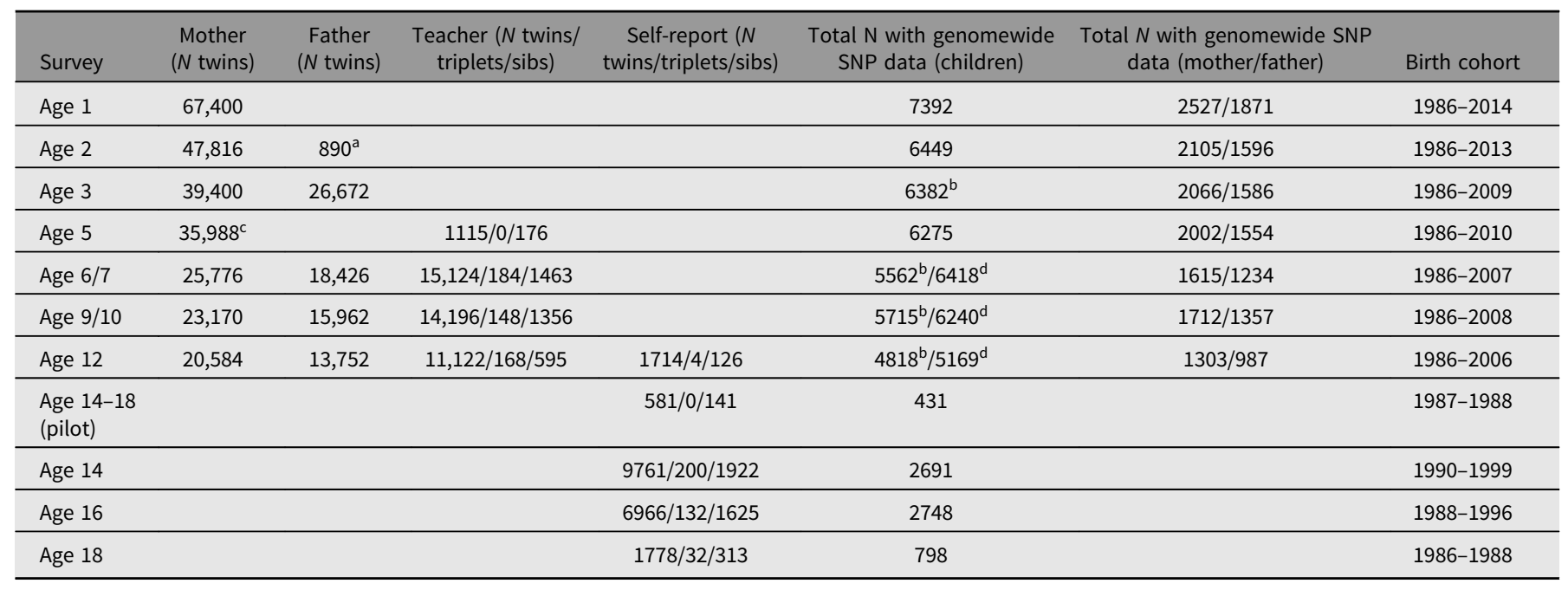

YNTR $=$ Young Netherlands Twin Register.

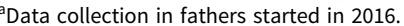

bMother or father report.

'Survey includes a father report.

${ }^{\mathrm{d}}$ Mother or father or teacher report.

Table 4. Numbers of completed surveys for adult participants (multiples, siblings, parents, spouses and offspring)

\begin{tabular}{|c|c|c|c|c|c|c|c|}
\hline \multicolumn{8}{|l|}{ ANTR } \\
\hline Survey (start year) & Multiples & Siblings & Parents & Spouses & Offspring & Total $N$ & $\begin{array}{l}\text { Total } N \text { with genomewide } \\
\text { SNP data }\end{array}$ \\
\hline Survey 1 (1991) & 3374 & 4 & 3013 & 0 & 0 & 6391 & 2610 \\
\hline Survey 2 (1993) & 4235 & 8 & 3662 & 0 & 0 & 7905 & 3736 \\
\hline Survey 3 (1995) & 3429 & 1481 & 3234 & 1 & 0 & 8145 & 3938 \\
\hline Survey 4 (1997) & 3233 & 1506 & 4 & 0 & 0 & 4743 & 2749 \\
\hline Survey 5 (2000) & 4619 & 1470 & 28 & 675 & 0 & 6792 & 3771 \\
\hline Survey 6 (2002) & 4538 & 1452 & 2851 & 1442 & 1 & 10,285 & 5862 \\
\hline Survey 7 (2004) & 6760 & 1663 & 4075 & 969 & 335 & 13,804 & 7689 \\
\hline Survey $0.1(2008)^{a}$ & 1216 & 52 & 156 & 157 & 120 & 1711 & 235 \\
\hline Survey 8 (2009) & 10,176 & 2142 & 6928 & 810 & 288 & 20,368 & 9587 \\
\hline Survey 9 (2011) & 5870 & 1269 & 4011 & 596 & 191 & 11,943 & 6639 \\
\hline Survey 10 (2013) & 9419 & 1854 & 7205 & 924 & 270 & 19,696 & 8629 \\
\hline Survey 11 (2015) & 8320 & 1639 & 5729 & 666 & 249 & 16,619 & 8310 \\
\hline Survey $0.2(2015)^{\mathrm{a}}$ & 886 & 105 & 627 & 30 & 38 & 1690 & 442 \\
\hline Survey 12 (2015) & 10,604 & 1761 & 8692 & 503 & 216 & 21,787 & 9439 \\
\hline YNTR/ANTR & & & & & & Total $N$ & $\begin{array}{l}\text { Total } N \text { with genomewide } \\
\text { SNP data }\end{array}$ \\
\hline Mothers of twins survey & & & & & & 20,140 & 3135 \\
\hline
\end{tabular}

ANTR $=$ Adult Netherlands Twin Register

${ }^{a}$ The surveys numbered 0.x run over longer periods and are sent to new ANTR participants; survey 0.2 is currently ongoing

of assisted reproduction techniques in the first survey, motor milestones at age 2 years, and academic performance and sharing the same school and/or classroom at ages 7 through 12 years.

ANTR surveys have focused on demographics, health and health behaviors, personality and wellbeing, as well as a broad range of behavioral and emotional problems as assessed by
ASEBA, Beck Depression Inventory, Personality Assessment Inventory - Borderline (PAI-BOR) scale, NEO Five-Factor Inventory and other instruments (Achenbach et al., 2017; Bouman et al., 1985; Costa \& McCrae, 1989; Morey, 2003). ANTR survey studies all address the general theme of individual differences of mental and physical health but often have a specific 
Table 5. Number of children with longitudinal parent and teacher reports (YNTR)

\begin{tabular}{lccccccc}
\hline Number of reports per child & 1 & 2 & 3 & 4 & 5 & 6 & 7 \\
\hline Mother report & 14,398 & 11,354 & 8996 & 9160 & 8244 & 8674 & 9448 \\
\hline Father report & 16,000 & 8510 & 7590 & 4978 & & & \\
\hline Teacher report & 19,324 & 9017 & 2746 & & & & \\
\hline
\end{tabular}

YNTR $=$ Young Netherlands Twin Register.

Table 6. Number of participants with longitudinal self-reports (YNTR and ANTR)

\begin{tabular}{lcccccccccccc}
\hline N self-reports YNTR & 1 & 2 & 3 & 4 & 5 & 6 & 7 & 8 & 9 & 10 & 11 & 12 \\
\hline Multiples & 8103 & 3978 & 2138 & 1315 & 1216 & 966 & 420 & 146 & 23 & 7 & 6 & 3 \\
\hline Siblings & 1633 & 796 & 405 & 283 & 218 & 159 & 61 & 15 & 4 & 3 & 0 & 0 \\
\hline Parents & 6153 & 2115 & 1417 & 1088 & 855 & 185 & 28 & 4 & 0 & 1 & 0 & 0 \\
\hline Total & 15,889 & 6889 & 3960 & 2686 & 2289 & 1310 & 509 & 165 & 27 & 11 & 6 & 3 \\
\hline N self-reports ANTR & 1 & 2 & 3 & 4 & 5 & 6 & 7 & 8 & 9 & 10 & 11 & 12 \\
\hline Multiples & 3520 & 1692 & 1553 & 1307 & 1081 & 1100 & 705 & 626 & 422 & 387 & 290 & 153 \\
\hline Siblings & 957 & 647 & 426 & 310 & 243 & 221 & 186 & 162 & 163 & 78 & 1 & 1 \\
\hline Parents & 2442 & 1258 & 969 & 556 & 458 & 379 & 356 & 294 & 393 & 255 & 2 & 0 \\
\hline Spouses & 825 & 519 & 314 & 210 & 171 & 165 & 149 & 30 & 0 & 0 & 0 & 0 \\
\hline Offspring & 184 & 125 & 92 & 80 & 72 & 53 & 0 & 0 & 0 & 0 & 0 & 0 \\
\hline Other & 13 & 6 & 9 & 3 & 3 & 0 & 0 & 0 & 0 & 0 & 0 & 0 \\
\hline Total & 7941 & 4247 & 3363 & 2466 & 2028 & 1918 & 1396 & 1112 & 978 & 720 & 293 & 154 \\
\hline
\end{tabular}

YNTR $=$ Young Netherlands Twin Register; ANTR $=$ Adult Netherlands Twin Register

Note: The top part of the table, ('YNTR') includes self-reports from YNTR twins and siblings at ages 14, 16 and 18 years, as well as self-reports by these participants after they enrolled in the ANTR as adults. In the bottom part of the table, ('ANTR') are the participants who registered as adolescents between 1991 and 1995, and adults.

focus, for example, survey 9 was focused on pain, survey 11 mainly included a large food preference assessment and survey 12 was developed for online phenotyping of major depressive disorder (BIONIC; Bot et al., 2017). At the same time, we try to maintain continuity for topics such as substance use, sports and exercise behavior, personality and wellbeing, in order to facilitate longitudinal comparisons. Tables 5 and 6 show the longitudinal survey participation in YNTR and ANTR: the number of participations of any single individual across studies. Please note that these tables are snapshots of the current numbers, as data collection and data entry are ongoing processes. A distinction is made between self-reports (YNTR and ANTR) and parent and teacher reports (YNTR only).

Triplets are a unique group of multiples within the NTR. The NTR has registered a total of 871 complete sets of triplets. ANTR triplets complete the regular surveys sent to all NTR participants. In the YNTR, dedicated triplet surveys are used, which follow the line of the twin data collection.

\section{Nonsurvey-Based Phenotyping}

In addition to participating in the longitudinal surveys, subgroups of twins and their family members are invited to take part in dedicated studies of, for example, autonomic nervous system functioning and cardiovascular risk, brain structure and function, neurocognitive test performance and IQ, or (an)aerobic fitness and daily physical activity. A second approach to phenotyping has been to conduct large-scale telephone interviews. These included monthly interviews on motor development and psychopathology with mothers about their young twins (Langendonk et al., 2007) and interviews to assess clinical diagnoses of ADHD (Derks et al., 2008). In ANTR participants, a series of Composite International Diagnostic Interviews (Wittchen, 1994) were conducted to obtain DSM-IV diagnoses of mental disorders, including major depressive disorder (Middeldorp et al., 2005).

A subset of these studies is presented in Table 7 . The table indicates the type of data collected per study, categorized into broad domains and a primary reference for each study. The same study domains are listed in Table 8 , where the overlap with other data collections is shown. Selection for participation in nonsurvey studies may be random, but can also be based on survey data, demographic information, or the availability of, for example, omics data. Examples are studies that included twins from specific age or birth cohorts (Bartels et al., 2002b; Hoekstra et al., 2007; Polderman, Posthuma et al., 2006; Rietveld et al., 2003; van Baal et al., 1998), twins with an older sibling (van Leeuwen et al., 2009; van Soelen et al., 2010) or twin-pairs concordant or discordant for a specific phenotype, such as anaesthesia (Bartels et al., 2009), attention problems (Derks et al., 2008; Polderman, Posthuma et al., 2006; van't Ent et al., 2007), depression (de Geus et al., 2007), obsessive-compulsive symptoms (den Braber et al., 2008) and body mass index (Doornweerd et al., 2016).

The academic achievement tests administered by Dutch schools are another important resource for phenotype information. Data are obtained from a standardized test administered in Grade 6, and the Pupil Monitoring System (PMS; Grades 1-6). In addition, 
Table 7. Overview of nonsurvey projects

\begin{tabular}{|c|c|c|c|c|c|c|c|c|c|}
\hline \multirow[b]{2}{*}{ Project } & \multirow[b]{2}{*}{ Main reference } & \multirow[b]{2}{*}{ Study population (age) } & \multirow[b]{2}{*}{$N$} & \multicolumn{5}{|c|}{ Primary research domain } & \multirow[b]{2}{*}{ Specifics } \\
\hline & & & & $\mathrm{CV}$ & EEG & IMG & $\mathrm{NC} / \mathrm{IQ}$ & PA INT & \\
\hline Stress and CV 1 & $\begin{array}{l}\text { Boomsma } \\
\text { et al. (1996) }\end{array}$ & $\begin{array}{l}\text { Adolescent twins } \\
(14-21)+\text { parents }\end{array}$ & 642 & $x$ & & & & & Lab: rest and stress measures, incl. BP \\
\hline Stress and CV 2 & $\begin{array}{l}\text { Snieder et al. } \\
(1997)\end{array}$ & Adult twins & 427 & $x$ & & & & & Lab: rest and stress measures, incl. BP \\
\hline Diabetes study & $\begin{array}{l}\text { Simonis-Bik } \\
\text { et al. (2008) }\end{array}$ & Adult twins and sibs & 189 & $x$ & & & & & $\begin{array}{l}\text { Diabetes, } \beta \text {-cell function, glucose } \\
\text { tolerance, BP }\end{array}$ \\
\hline NTR-VUAMS1 & $\begin{array}{l}\text { de Geus et al. } \\
(2005)\end{array}$ & Adult twins and sibs & 458 & $x$ & & & & & $24 \mathrm{~h}$ ambulatory assessment incl. BP \\
\hline NTR-VUAMS2 & $\begin{array}{l}\text { Kupper et al. } \\
(2004)\end{array}$ & Adult twins and sibs & 428 & $x$ & & & & & $24 \mathrm{~h}$ ambulatory assessment incl. BP \\
\hline NTR-VUAMS3 & $\begin{array}{l}\text { Neijts et al. } \\
(2015)\end{array}$ & Adult twins and sibs & 593 & $x$ & & & & & $\begin{array}{l}24 \mathrm{~h} \text { ambulatory assessment incl. BP, } \\
\text { short stress test }\end{array}$ \\
\hline EEG \& Cognition & $\begin{array}{l}\text { Van Baal et al. } \\
\text { (1998) }\end{array}$ & Young twins $(5 / 7)$ & 418 & & $x$ & & $x$ & & EEG, ERP, IQ, HR \\
\hline Cognition $^{a}$ & $\begin{array}{l}\text { Rietveld et al. } \\
(2003)\end{array}$ & Young twins (10) & 394 & & & & $x$ & & IQ \\
\hline Cognition $^{a}$ & $\begin{array}{l}\text { Bartels et al. } \\
(2002 a)\end{array}$ & Young twins (12) & 364 & & & & $x$ & & IQ, hormones \\
\hline $\begin{array}{l}\text { Cognition and } \\
\text { hormones }^{b}\end{array}$ & $\begin{array}{l}\text { Hoekstra et al. } \\
(2007)\end{array}$ & $\begin{array}{l}\text { Adolescent twins and } \\
\text { sibs (18) }\end{array}$ & 508 & $x$ & & & $x$ & & $\begin{array}{l}\text { IQ, cardiovascular measures, growth, } \\
\text { hormones }\end{array}$ \\
\hline WebCNP & $\begin{array}{l}\text { Swagerman } \\
\text { et al. (2016) }\end{array}$ & $\begin{array}{l}\text { Twins, sibs, parents } \\
(10-86)\end{array}$ & 1110 & $x$ & & & $x$ & & $\begin{array}{l}\text { Computerized Neuropsychological Testing } \\
\text { System }\end{array}$ \\
\hline Attention and IQ & $\begin{array}{l}\text { Groot et al. } \\
(2004)\end{array}$ & Young twins (5) & 474 & & & & $x$ & & IQ, ANT, behavior surveys \\
\hline Attention and IQ & $\begin{array}{l}\text { Polderman, } \\
\text { Gosso et al. } \\
(2006)\end{array}$ & Young twins (12) and sibs & 409 & $x$ & & & $x$ & & IQ, ANT, hormones, behavior surveys \\
\hline Attention and IQ & $\begin{array}{l}\text { Huguet et al. } \\
(2017)\end{array}$ & $\begin{array}{l}\text { Adolescent twins } \\
(17 / 18)\end{array}$ & 332 & $x$ & & & $x$ & & Raven advanced, NEO \\
\hline EEG adolescents & $\begin{array}{l}\text { van } \\
\text { Beijsterveldt } \\
\text { et al. (1996) }\end{array}$ & $\begin{array}{l}\text { Adolescent twins } \\
(16 / 18)\end{array}$ & 426 & & $x$ & & $\mathrm{x}$ & & EEG, ERP, IQ, HR, NCV \\
\hline EEG adults & $\begin{array}{l}\text { Posthuma } \\
\text { et al. (2005) }\end{array}$ & $\begin{array}{l}\text { Adult twins and sibs } \\
(25-55)\end{array}$ & 785 & & $x$ & & $\mathrm{x}$ & & EEG, cognitive tasks, IQ, HR, BP \\
\hline Brainscale1 & $\begin{array}{l}\text { van Leeuwen } \\
\text { et al. (2008) }\end{array}$ & Young twins (9) and sibs & 330 & & & $x$ & $x$ & & MRI, IQ, neurocognitive tests, hormones \\
\hline Brainscale2 & $\begin{array}{l}\text { van Soelen } \\
\text { et al. (2012) }\end{array}$ & Young twins (12) and sibs & 261 & & & $x$ & $x$ & & $\begin{array}{l}\text { MRI, IQ, neurocognitive tests, hormones, } \\
\text { behavior surveys }\end{array}$ \\
\hline Brainscale3 & $\begin{array}{l}\text { Teeuw et al. } \\
(2019)\end{array}$ & $\begin{array}{l}\text { Adolescent twins (17) and } \\
\text { sibs }\end{array}$ & 246 & $x$ & & $x$ & $x$ & & $\begin{array}{l}\text { MRI, IQ, neurocognitive tests, hormones, } \\
\text { behavior surveys }\end{array}$ \\
\hline MRI & $\begin{array}{l}\text { Baaré et al. } \\
(2001)\end{array}$ & Adult twins and siblings & 160 & & & $x$ & & & MRI \\
\hline MRI OCD & $\begin{array}{l}\text { den Braber } \\
\text { et al. (2010) }\end{array}$ & Adult twins (conc./disc. OCD) & 209 & & & $x$ & & & MRI, The Padua Inventory Abbreviated \\
\hline MRI DOS & $\begin{array}{l}\text { den Braber } \\
\text { et al. (2013) }\end{array}$ & Adult opposite sex twins & 40 & & & $x$ & & & MRI \\
\hline MRI MDD & $\begin{array}{l}\text { de Geus et al. } \\
2007\end{array}$ & Adult twins (conc./disc. MDD) & 65 & & & $x$ & & & MRI \\
\hline MRI BMI & $\begin{array}{l}\text { Doornweerd } \\
\text { et al. (2018) }\end{array}$ & Adult twins (disc. BMI) & 92 & & & $x$ & & & MRI, interview, anthropometric data, BP \\
\hline MRI/PET & $\begin{array}{l}\text { Konijnenberg } \\
\text { et al. (2018) }\end{array}$ & Elderly MZ twin-pairs $(60+)$ & 205 & & & $x$ & & & $\begin{array}{l}\text { MRI, PET, neuropsychological tests, } \\
\text { physical examination, carotid artery } \\
\text { ultrasound, BP }\end{array}$ \\
\hline MRI ADHD & $\begin{array}{l}\text { van't Ent et al. } \\
(2009)\end{array}$ & $\begin{array}{l}\text { Young MZ twins } \\
\text { (conc./disc. ADHD) }\end{array}$ & 74 & & & $x$ & & & MRI, Stroop task, flanker task \\
\hline
\end{tabular}


Table 7. (Continued)

\begin{tabular}{|c|c|c|c|c|c|c|c|c|c|c|}
\hline Project & Main reference & Study population (age) & $N$ & \multicolumn{6}{|c|}{ Primary research domain } & Specifics \\
\hline MEG & $\begin{array}{l}\text { van't Ent et al. } \\
(2010)\end{array}$ & Young adult twins & 74 & & & $\mathrm{x}$ & & & & $\begin{array}{l}\text { MEG-recorded somatosensory-evoked } \\
\text { fields }\end{array}$ \\
\hline Fitness & $\begin{array}{l}\text { Schutte et al. } \\
\text { (2016) }\end{array}$ & Adolescent twins and sibs & 481 & & & & & $x$ & & Lab experiment, surveys and interview \\
\hline Physical activity & $\begin{array}{l}\text { Schutte et al. } \\
\text { (2019) }\end{array}$ & Young adult twins & 774 & & & & & $x$ & & 7 days triaxial accelerometer (hip) \\
\hline CIDI & $\begin{array}{l}\text { Middeldorp } \\
\text { et al. (2007) }\end{array}$ & Twins, sibs and parents & 1438 & & & & & & $x$ & CIDI \\
\hline $\begin{array}{l}\text { ADHD clinical } \\
\text { study }\end{array}$ & $\begin{array}{l}\text { Derks et al. } \\
(2008)\end{array}$ & Young twins (mother report) & 1116 & & & & & & $x$ & Diagnostic Interview Schedule for Children \\
\hline $\begin{array}{l}\text { Motor } \\
\text { milestones }\end{array}$ & $\begin{array}{l}\text { Langendonk } \\
\text { et al. (2007) }\end{array}$ & Young twins $(0.5-2)$ & 470 & & & & & & $\mathrm{x}$ & Telephone interview motor milestones \\
\hline
\end{tabular}

$\mathrm{CV}=$ cardiovascular/(ambulatory) autonomic nervous system; EEG = EEG/ERP; IMG = imaging; NC/IQ = neurocognitive testing/IQ; PA = fitness/physical exercise; INT = interview; BP = blood pressure; $\mathrm{HR}=$ heart rate; $\mathrm{ANT}=$ Amsterdam Neuropsychological Tasks; $\mathrm{NCV}=$ nerve conduction velocity; conc. $=$ concordant; disc. $=$ discordant; OCD $=$ obsessive-compulsive disorder;

$\mathrm{MDD}=$ major depressive disorder; BMI = body mass index; CIDI = composite international diagnostic interview; NTR-VUAMS = NTR Vrije Universiteit Ambulatory Monitoring System; ERP = Event related potential; WebCNP = The (web-based) University of Pennsylvania Computerized Neuropsychological Test Battery; MRI = magnetic resonance imaging; DOS = dizygotic opposite sex twins; PET = Positron emission tomography; ADHD = Attention deficit hyperactivity disorder; MEG = Magnetoencephalography.

${ }^{\mathrm{a} E E G} \&$ Cognition sample.

bEEG \& Cognition sample plus additional participants.

the regular surveys to parents and teachers during the elementary school years include items on children's school grades (van Bergen et al., 2018). NTR started to collect information on standardized educational achievement tests in 2000 (Bartels et al., 2002b). The test is administered nationwide over a period of 3 days in the last grade of elementary school at $\sim 12$ year (Eindtoets Basisonderwijs 2002; www.cito.nl). Initially, these scores were obtained from teachers. Because results become available near the very end of the school year, we later asked parents and twins to report these scores. The correlation between scores provided by parents and twins is $0.96(N=3314)$ and between teachers and twins the correlation is $0.93(N=922)$.

In 2008, the NTR started to collect PMS data, providing information on academic achievement throughout elementary school. Since 2014/2015, all elementary schools are required to use a PMS. The PMS consists of grade appropriate tests, independent of teaching methods, which are administered at fixed time points (i.e., beginning, halfway and/or end of the school year) in each grade. The PMS has tests on all important educational domains, for example, reading, mathematics and spelling (de Zeeuw et al., 2016). Currently, around one-third of the teachers who fill out a survey also send us a student report with the results from the PMS tests of the current and previous grades.

\section{Twinning}

A phenotype of special interest for which nearly every NTR participant is informative is the trait 'being a twin' or 'being a parent of twins'. Among the earliest NTR projects was a study on the inheritance of twinning. In the early 1990s, telephone interviews were held with the mothers of DZ twins (Meulemans et al., 1996) to collect information on twinning in their extended pedigree for segregation analyses, and to assess zygosity in the proband twins and any additional twins in the pedigree. These pedigree data formed the basis for several blood collection projects in 'twinning pedigrees', initially with the purpose of linkage studies in sister-pairs (Painter et al., 2010) and later for genomewide association studies (Mbarek et al., 2016). A large survey study collected information on risk factors for twinning in both mothers from the YNTR/ANTR and the ANTR (Hoekstra et al., 2008, 2010). Table 9 describes the characteristics of the pedigrees within NTR, including special groups of participants relevant to twinning research, such as families with more than one twin-pair.

\section{Record Linkage/Cross-Referencing the NTR Database to Other National Databases}

Starting with ANTR survey 6, participants were asked for permission for record linkage with other databases in the Netherlands. Across surveys, on average $81 \%$ of participants agreed with record linkage, $14 \%$ did not agree and 5\% did not answer the question. Subjects who did not agree or did not answer the question are excluded from record linkage.

Projects that have made use of record linkage include a large study of chorionicity (van Beijsterveldt et al., 2016). Information on chorionicity through record linkage as well as access to tissue samples was available from in the Pathological Anatomy National Automatic Archive (PALGA), a nationwide network and register of histopathology and cytopathology database and biobank. Other projects that made use of the PALGA database include studies on triplets and a study of cervix smear abnormalities (Lamb et al., 2012; van Beijsterveldt et al., 2016; Vink et al., 2011). Valuable information can also be obtained by linking the NTR databases to national population-based registers such as the cancer registration in the Netherlands. A facility has been created in collaboration with Statistics Netherlands (https://www.cbs.nl/en-gb), to combine data from multiple databases for analysis. This 'ODISSEI Data Facility (ODF)' (www.odissei-data.nl) enables, for example, the analysis of NTR genotype information with phenotype information from Statistics Netherlands.

\section{Harmonization and Data Repository}

Given the large amount of data collected over the last decades, and the diversity in research topics and data collections that have 
Table 8. Sample sizes biological and nonsurvey data, and overlap with surveys

\begin{tabular}{|c|c|c|c|}
\hline & Total $N$ & $\begin{array}{l}\text { YNTR } \\
\text { survey }\end{array}$ & $\begin{array}{l}\text { ANTR } \\
\text { survey }\end{array}$ \\
\hline \multicolumn{4}{|l|}{ Survey data } \\
\hline YNTR survey $^{a}$ & 147,360 & 147,360 & 24,072 \\
\hline ANTR survey & 52,039 & 24,072 & 52,039 \\
\hline \multicolumn{4}{|l|}{ Biological samples } \\
\hline DNA (blood or buccal) & 29,138 & 15,984 & 19,397 \\
\hline Genomewide SNPs & 26,146 & 14511 & 17,704 \\
\hline DNA methylation whole blood $450 \mathrm{~K}$ & 3025 & 355 & 2942 \\
\hline DNA methylation buccal $450 \mathrm{~K}$ & 22 & 22 & 21 \\
\hline DNA methylation buccal $850 \mathrm{~K}$ & 1526 & 1526 & 58 \\
\hline DNA sequencing whole blood & 349 & 9 & 330 \\
\hline RNA expression U219 array & 3370 & 284 & 3231 \\
\hline RNA sequencing & 1606 & 256 & 1561 \\
\hline RNA sequencing LPS-stimulated samples & 390 & 13 & 380 \\
\hline Metabolomics in serum or plasma & 6485 & 621 & 6311 \\
\hline Metabolomics in urine & 1564 & 1564 & 156 \\
\hline Microbiome & 568 & 187 & 561 \\
\hline Hair sample & 222 & 7 & 222 \\
\hline \multicolumn{4}{|l|}{ Biomarkers $^{\mathrm{b}}$} \\
\hline Cholesterol, HDL, LDL, triglycerides & 10,860 & 1328 & 9729 \\
\hline Immune parameters & 10,115 & 1318 & 9240 \\
\hline Cortisol (in saliva) & 2980 & 1303 & 2535 \\
\hline \multicolumn{4}{|l|}{ Non-survey projects ${ }^{\mathrm{C}}$} \\
\hline Cardiovascular/ambulatory ANS & 3589 & 1132 & 3141 \\
\hline EEG & 1520 & 437 & 1319 \\
\hline Imaging (MRI, MEG, PET) & 893 & 220 & 830 \\
\hline Neurocognitive/IQ & 3726 & 2081 & 2955 \\
\hline Physical activity & 1255 & 831 & 1139 \\
\hline Interview & 3013 & 1597 & 1994 \\
\hline \multicolumn{4}{|l|}{ Other } \\
\hline Blood pressure & 3548 & 263 & 3238 \\
\hline
\end{tabular}

YNTR = Young Netherlands Twin Register; ANTR = Adult Netherlands Twin Register; LPS = Lipopolysaccharide; HDL = high-density lipoprotein; LDL = low-density lipoprotein; ANS = autonomic nervous system; $E E G=$ electroencephalography; $M R I=$ magnetic

resonance imaging; $M E G$ = Magnetoencephalography; $\mathrm{PET}=$ Positron emission tomography; $\mathrm{IQ}=$ Intelligence Quotient.

${ }^{a}$ Count includes children whose parents and teachers reported about them as well as parents reporting about themselves and each other.

bimited selection; not all measured biomarkers are listed.

'See also Table 7.

evolved over the years, the need arose for the NTR to harmonize the data collected across multiple projects and to bring all these resources together. This should ensure that the large amount of data collected since the beginning of the NTR becomes accessible under Findable, Accessible, Interoperable, Reusable (FAIR) data stewardship principles and can be optimally used in research on behavior and health. For this purpose, we are building a new data repository for the phenotype data, as well as an online data showcase, in collaboration with IT company The Hyve (https:// thehyve.nl/).

\section{NTR Data Showcase}

The NTR Data Showcase was designed to facilitate data requests from NTR and affiliated researchers, by allowing them to see what data are available in the NTR. The NTR Data Showcase does not contain the actual research data, only metadata. Users can search items by keyword, project or research domain. The research domains are based on the domain structure as used by Maelstrom Research (https://www.maelstrom-research.org), supplemented with NTR-specific subdomains (e.g., twin-specific variables such as zygosity) where necessary. Researchers can view properties of the available variables, including the item name, keywords, a brief description of the measure, the original phrasing of survey questions in Dutch and English, the data type (string/numeric/categorical), labels and subject counts. Once a set of variables is identified, the items can be collected in a 'shopping cart' and exported to a.JSON (JavaScript Object Notation) file, to become part of a data request.

\section{NTR Data Repository}

The phenotypic research data are stored in a TranSMART data warehouse (https://transmartfoundation.org/), which can be accessed by the NTR data managers using the Glowing Bear application (https://glowingbear.app/). All data for a participant, which may have been collected in many separate research projects, are stored under the same numeric person ID. TranSMART also implements the use of 'concepts': if the same variable was collected in many different projects (e.g., a certain personality questionnaire that was included in many different projects), and was measured and coded in the same way across all projects, these variables can be linked to a single concept, after which all of them can be extracted at once with a simple query. Once a researcher has applied for a dataset and the request has been approved by the NTR data access committee, a JSON file exported from the NTR Data Showcase can be uploaded in the Glowing Bear application by a data manager to extract the requested dataset. In addition to importing these JSON files, which contain the variable selection, cohort selections can be specified by the data managers, based on, for example, participation in a particular research project, person characteristics (e.g., age or sex), availability of genotype data or family relationships (e.g., 'all individuals who are a mother of twins'). The queries used to extract a specific dataset can be stored and reused in case an update of the dataset is necessary.

Contact information of all participants is stored in the Person Administration of the Netherlands Twin Register (PANTER) database (Boomsma et al., 2008). This person-oriented database stores contact details and family relationships between persons (Boomsma et al., 2018) in a secure environment that is not connected to the internet. In the PANTER database, participants are stored under an administrative ID which is different from the IDs used for research data (e.g., phenotype and omics data), so that personal and research data remain separated.

\section{NTR Biomarker and Omics Projects}

The first two large-scale NTR studies $(N=936)$ on cardiovascular risk factors in twin families included assessment of biomarkers such as lipid levels, plant sterols, $\mathrm{Lp}$ (a) glucose and other biomarkers (Kempen et al., 1991; Snieder et al., 1997). Of note, 20 years later nearly half of the participants in the early 90 s projects $(N=510)$ also took part in the NTR biobank studies as described below, creating possibilities for longitudinal biomarker studies. 
Table 9. The NTR Pedigree as of April 2019

\begin{tabular}{|c|c|c|}
\hline NTR Pedigree information & Individuals & Complete pairs $^{a}$ \\
\hline Total $N$ & \multicolumn{2}{|l|}{255,785} \\
\hline Multiples & $123,157^{b}$ & 60,406 \\
\hline Twins - total & 119,040 & 59,520 \\
\hline Twins - MZ & 29,882 & 14,941 \\
\hline Twins - DZ-same sex & 28,786 & 14,393 \\
\hline Twins — DZ-opposite sex & 37,932 & 18,966 \\
\hline Twins - unknown zygosity & 22,440 & 11,220 \\
\hline Triplets & 2613 & 871 \\
\hline Quadruplets & 52 & 13 \\
\hline Quintuplets & 10 & 2 \\
\hline \multicolumn{3}{|l|}{ Parental generation } \\
\hline Parents & \multicolumn{2}{|c|}{$\begin{array}{c}115,702 \text { (113,923 multiple } \\
\text { parents) }\end{array}$} \\
\hline Multiples who are parents of multiples & \multicolumn{2}{|c|}{1662 individuals (730 families ${ }^{c}$ ) } \\
\hline \multicolumn{3}{|l|}{ Families where twins/sibs have offspring } \\
\hline Families with sib pairs who both have offspring ${ }^{d}$ & \multicolumn{2}{|c|}{469} \\
\hline Families with twin/multiple pairs who both have offspring ${ }^{d}$ & \multicolumn{2}{|c|}{$136^{\mathrm{e}}$} \\
\hline Families with sib pairs who both have twin/multiple offspring & \multicolumn{2}{|c|}{378} \\
\hline Families with twin-pairs who both have twin/multiple offspring & \multicolumn{2}{|c|}{$12^{f}$} \\
\hline \multicolumn{3}{|l|}{ Family size } \\
\hline Number of extended families & \multicolumn{2}{|c|}{59,694 (933 $n=1$ families) } \\
\hline Typical family size $(n)$ & \multicolumn{2}{|c|}{4 (43,374 families) } \\
\hline Largest family $(n)$ & \multicolumn{2}{|c|}{39 (1 family) } \\
\hline Typical number of twin-pairs/sets of multiples in a family $(n)$ & \multicolumn{2}{|c|}{1 (56,468 families) } \\
\hline Families with more than one multiple & \multicolumn{2}{|c|}{2549 families } \\
\hline Largest number of twin-pairs/sets of multiples in a family $(n)$ & \multicolumn{2}{|c|}{7 (1 family) } \\
\hline Typical number of generations $(n)$ & \multicolumn{2}{|c|}{$2(57,167$ families $)$} \\
\hline Largest number of generations $(n)$ & \multicolumn{2}{|c|}{4 (145 families) } \\
\hline
\end{tabular}

NTR $=$ Netherlands Twin Register.

aA pair indicates a complete set of multiples, that is, two twins, three triplets, four quadruplets or five quintuplets.

${ }^{b}$ Number includes 1442 multiples who are registered without a co-twin. These are often individuals who registered because they

are a parent or spouse of a twin. They are not included in counts of twins, triplets, and so on.

'Families where both parent and offspring are multiples, and the parent's co-twin is also registered.

${ }^{\mathrm{d}}$ This includes multiple offspring as well as singleton offspring.

${ }^{e}$ Number includes 21 families in which one or more siblings and both members of a twin-pair all have offspring.

f Number includes two families in which one or more siblings and both members of a twin-pair all have twin/multiple offspring.

In 2004, the NTR started a large biological sample collection in nearly 10,000 participants to create a resource for future omics and biomarker studies as well as the creation of immortalized cell lines: the NTR biobank (Willemsen et al., 2010). We first carried out a large pilot project (Hoekstra et al., 2004) in which we established the feasibility of, for example, drawing blood from fertile women on day 2-4 of the menstrual cycle, or in their pill-free week. Between 2004 and 2008, a group of adult participants from NTR research projects was invited for the NTR biobank study, of which $69 \%$ participated. A comparison of nonparticipants with participants showed that nonparticipants were less often female (52\% vs. 64\%), were slightly younger (average birth year 1963 vs. 1960 in men, 1964 vs. 1962 in the women) and had less often received higher education ( $27 \%$ vs. $39 \%$ in men, $22 \%$ vs. $33 \%$ in women). During a morning home visit, eight tubes of fasting blood and a morning urine sample were collected along with phenotypic information on health, medication use, body composition and smoking. A second project between 2008 and 2010 added collection of stool samples in mainly MZ twin-pairs (Sirota et al., 2015). In both projects, extensive cell counts were realized in fresh blood samples (Lin et al., 2017). These data on cell counts serve as important covariates in transcriptomics (e.g., Jansen et al., 2014) and epigenomics studies (van Dongen et al., 2016). Biomarkers assessed for all NTR biobank participants include lipids, glucose, insulin, HbA1c, liver enzymes (van Beek et al., 2015), C-reactive protein, fibrinogen, interleukin (IL)-6, TNF- $\alpha$ and soluble IL-6 receptor (van Dongen et al., 2015). Other biomarkers collected in (large) subsets of samples include cotinine in blood (Bot et al., 2013), telomere length (Broer et al., 2013) and microbiome datasets (Finnicum et al., 2018). 


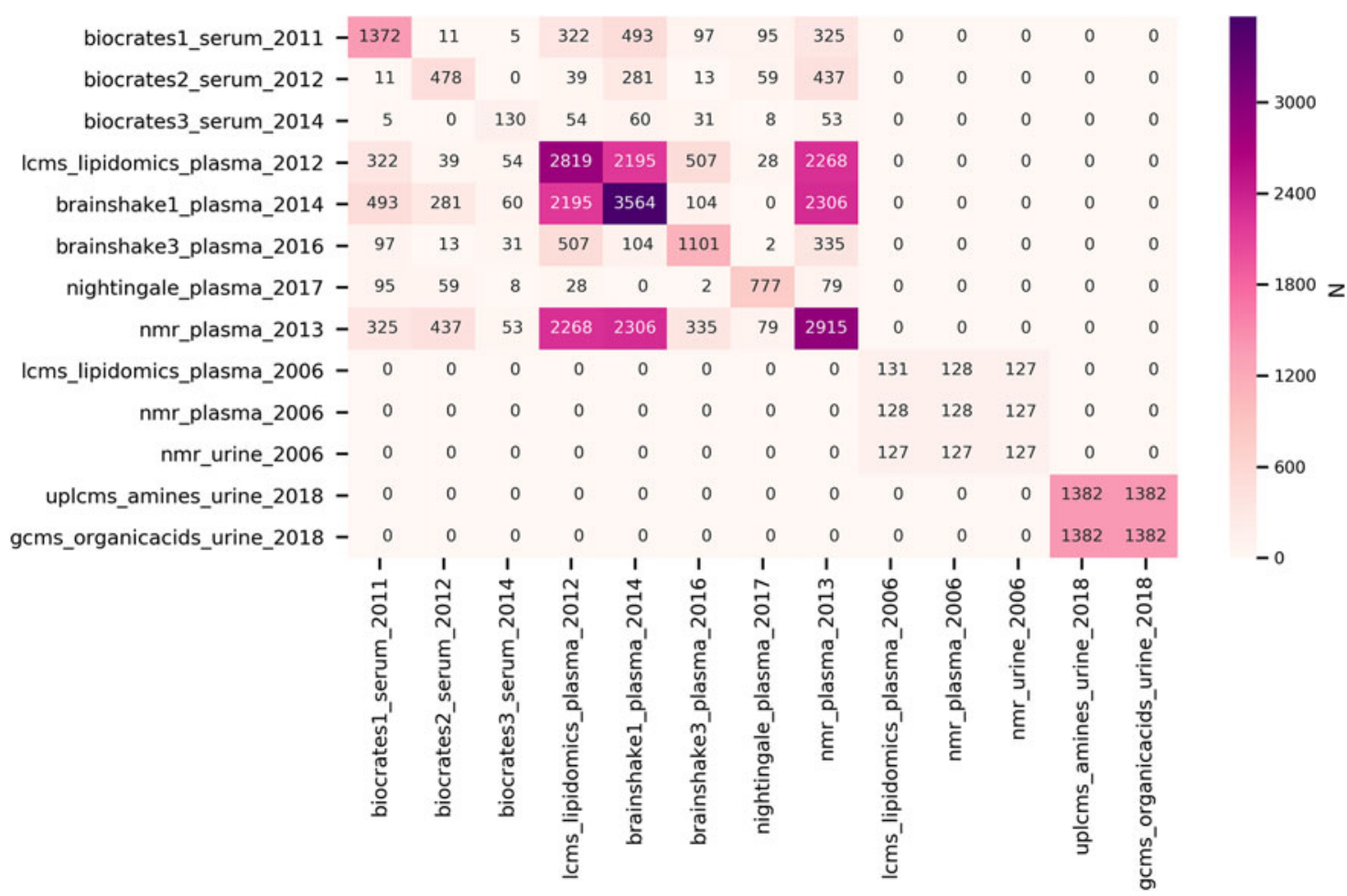

Fig. 1. Subject overlap between the NTR metabolomics datasets. The datasets are denoted by metabolomics platform, sample material/tissue and year of measurement. Note that the values on the diagonal represent the sample size of the individual datasets. All data assessed before 2018 are from adults, all data assessed in 2018 are from 9-year-olds.

DNA collection constituted an important element of the biobanking project, continuing the effort in many earlier NTR studies that also collected DNA samples from twin families, for instance, as part of linkage studies into depression and anxiety (Boomsma et al., 2000), asthma (Wu et al., 2010) and twinning pedigrees (Painter et al., 2010), or as part of the nonsurvey projects listed in Table 7. DNA collection continues for participants who provided phenotype information, for example, as part of a large transatlantic collaboration with the Avera Institute of Human Genetics (Ehli et al., 2017). DNA has been collected from whole blood for the majority of the ANTR subjects and by buccal swabs in the majority of YNTR families. Our buccal swab procedures yield high-quality DNA amenable to multiple omics arrays (Meulenbelt et al., 1995; Min et al., 2006). For twins, we aim to always collect buccal DNA, often in addition to DNA from whole blood.

In the DNA and RNA resources in the NTR biobank, substantial progress was made in assessing epigenetic, transcriptomics and metabolomics data. Epigenetic and RNA expression data have been measured in MZ and DZ twin-pairs (van Dongen et al., 2016; Wright et al., 2014). Analyses of these data, making use of the classical twin design, showed significant heritability for both the transcriptome and the epigenome. Figure 1 summarizes the metabolomics data that have been measured in blood for adults and in urine for 9-year-old twins. In adults, for over 5100 individuals, metabolomics data have been realized from 4 metabolomics platforms: the Nightingale Health $1 \mathrm{H}-\mathrm{NMR}$ platform (previously referred to as Brainshake), a UPLC-MS Lipidomics platform, the LUMC 1H-NMR platform and the Biocrates Absolute-IDQTM p150 platform (Draisma et al., 2013; Hagenbeek et al., 2019). In children, metabolomics data were assessed across three platforms for amines, organic acids and steroid hormones. The NTR biobank, combined with the extensive phenotypic information available within the NTR, provides a valuable resource for the study of genetic influences on individual differences in mental and physical health (see Table 8).

\section{Communication with Participants}

We observe that families that do not participate at one of more waves of data collection often participate again in subsequent waves ('drop-in'). Reasons for this include true changes in motivation and availability, but also participants moving to new addresses, which may be traced only after data collection for the current wave is closed. To bolster the motivation to stay involved, we have a website (http://www.tweelingenregister.org/) and a yearly newsletter, Twinfo, that is mailed to all families and also published on the website (http://www.tweelingenregister.org/ twinfo/). Two social media outlets are Facebook (https:// www.facebook.com/NederlandsTweelingenRegister/) and Twitter (https://twitter.com/NTR_VU; https://twitter.com/NTRscience). In addition, within a national collaboration of cohorts/biobanks (https://www.bbmri.nl/), the NTR has pioneered building a portal for participants. This 'My NTR' portal (https://www.mijnntr.nl/) provides selected personalized feedback on data provided by the participants (e.g., personality profile), in addition to general information on the outcomes of the research participants have contributed to (Bovenberg et al., 2016).

\section{Discussion}

We conclude this paper on the NTR by considering some exciting developments which we believe illustrate the continued value of twin-family data across multiple domains of research. 


\section{Polygenic Risk Scores to Detect the Effects of Nurture}

Two papers published last year (Bates et al., 2018; Kong et al., 2018) detailed an innovative method to measure intergenerational transmission in families where whole-genome genotyping is available in both parents and in their offspring. Parents transmit only one copy of each chromosome ( $50 \%$ of genome) to each offspring, but shape an environment for their offspring that is influenced by their own genome. The aggregate effect of an individual's genome on a trait can be summarized in a polygenic risk score (PRS). The PRS for the transmitted and nontransmitted parental genotypes can be separately associated with outcome traits. The nontransmitted genotypic effects on offspring's outcome traits can be interpreted as a direct measure of parenting behaviors and environments, unconfounded by the genomes transmitted to the offspring. This is also referred to as 'genetic nurturing'. Large genomewide association studies are required to estimate the transmitted and nontransmitted PRS, but these are increasingly becoming available. The second requirement is that offspring and parents are all genotyped (however, note that the phenotype information is only needed in the offspring). The NTR has nearly always aimed to collected DNA samples in extended twin families, that is, the index twins, their parents and siblings. In these NTR families, it is possible to construct PRS based on the transmitted and nontransmitted parental genomes for all traits with published summary statistics. These have now been calculated for 5902 offspring within NTR. We recently employed this design to seek evidence of genetic nurturing in adults' educational attainment and children's academic achievement and ADHD (de Zeeuw et al., 2019).

\section{Phenotypic Reference Panels}

When phenotyping for a trait, or a series of traits, has been carried out with different instruments, data integration methods for phenotype harmonization across instruments require or can greatly benefit from datasets where the different instruments have been administered to the same subjects (van Den Berg et al., 2014). In YNTR, we collected such a reference panel for phenotype data to harmonize multiple measures of aggression and other behavioral problems in schoolchildren as part of the ACTION project (Aggression in Children: Unraveling gene-environment interplay to inform Treatment and interventION strategies Consortium; http://www.action-euproject.eu/; Bartels et al., 2018; Luningham et al., 2017). Throughout 2016, the Child Behavior Check List (CBCL; Achenbach et al., 2017), the complete Strengths and Difficulties Questionnaire ( Goodman, 1997) plus a selection of A-TAC items (Autism-Tics, ADHD, and other Comorbidities inventory; Larson et al., 2010) were completed by both parents of twins born between September 2005 and October 2008. Hendriks et al. (2019) analyzed aggression data across these different instruments. Although agreement with respect to phenotypic diagnoses and correlations between continuous scores were moderate, genetic correlations indicated that the underlying construct of childhood aggression was consistent across measures.

\section{Children-of-Twins Design/Numbers for Exceptional Families}

Infant twins who were enrolled by their parents and for whom we have data since infancy are now becoming parents themselves. The NTR has started collecting multigenerational data in this unique group. Other interesting groups include multigenerational families where both parent and offspring are twins, as well as families where two siblings are both parents of twins, that is, the twin offspring are cousins. These data enable application of the Children-of-Twins (CoT) design (D’Onofrio et al., 2003), to disentangle the genetic and environmental transmission from parents to their offspring and give more insight into the causal role of the home environment on the development of children. The CoT design is based on the fact that offspring of MZ twins are as genetically related to the co-twin of their parent (uncle/aunt) as they are to their own parent, but only share a home environment with their own parents. For more details on the composition of the pedigrees within NTR, see Table 9.

\section{Mendelian Randomization Combined With the Twin Design}

One of the greatest challenges in the social, behavioral and medical sciences is to determine the causality underlying associations between a (putative) risk factor and a behavioral or disease outcome. Simple regression analysis cannot properly address this question. The correlation between two variables can reflect reverse causation or unobserved factors that influence both (confounding). Mendelian randomization $(\mathrm{MR})$ is a method based on instrumental variable analysis in econometrics that can be used to estimate the causal effect of a risk factor on a behavioral or health outcome, provided that genetic variants are known that influence the risk factor (Davey Smith \& Hemani, 2014; Palmer et al., 2011; Pierce et al., 2010). However, many genetic variants derived from genomewide association (GWA) meta-analyses have small effects, and so, when used as instrumental variables, render MR liable to weak instrument bias. PRS have the advantage of larger effects, but may be characterized by horizontal pleiotropy, which violates a central assumption of MR (Pickrell et al., 2016). We recently developed the MR-DoC twin model, which allows one to test causal hypotheses and to obtain unbiased estimates of the causal effect given strong but pleiotropic instruments (like PRS) by controlling for genetic and environmental influences common to the outcome and exposure (Minica et al., 2018). This method greatly increases the value of the large twin-family cohorts like the NTR and many others in this special issue.

In conclusion, we believe that twin studies and twin-family studies will continue to blossom into the next decades, and with the new data repository and data showcase under development, the NTR should be well prepared for the future.

Detailed background information on the NTR may also be found on the website http://www.tweelingenregister.org/. This website originated as an information resource for participants and also includes the nearly complete list of publications.

Acknowledgments. We warmly thank all twin families who participated in the research projects described in this paper.

Funding. Funding was obtained from the Netherlands Organization for Scientific Research (NWO) and The Netherlands Organisation for Health Research and Development (ZonMW) grants 904-61-090, 985-10-002, 912 10-020, 904-61-193,480-04-004, 463-06-001, 451-04-034, 400-05-717, Addiction-31160008, 016-115-035, 481-08-011, 056-32-010, Middelgroot911-09-032, OCW_NWO Gravity program-024.001.003, NWO-Groot 48015-001/674, NWO Veni 451-15-017, Center for Medical Systems Biology (CSMB, NWO Genomics), NBIC/BioAssist/RK(2008.024), Biobanking and Biomolecular Resources Research Infrastructure (BBMRI-NL, 184.021.007 and 184.033.111); Spinozapremie (NWO-56-464-14192), KNAW Academy Professor Award (PAH/6635) and University Research Fellow grant (URF) to DIB; Amsterdam Public Health research institute (former EMGO+), Neuroscience Amsterdam research institute (former NCA); the European Science Foundation (ESF, EU/QLRT-2001-01254), the European Community's Seventh Framework Program (FP7-HEALTH-F4-2007-2013, grant 01413: ENGAGE and grant 602768: ACTION); the European Research Council (ERC Starting 284167, ERC Consolidator 771057, ERC Advanced 
230374), Rutgers University Cell and DNA Repository (NIMH U24 MH068457-06), the National Institutes of Health (NIH, R01D0042157-01A1, R01MH58799-03, MH081802, DA018673, R01 DK092127-04, Grand Opportunity grants 1RC2 MH089951 and 1RC2 MH089995); the Avera Institute for Human Genetics, Sioux Falls, South Dakota (USA). Part of the genotyping and analyses were funded by the Genetic Association Information Network (GAIN) of the Foundation for the National Institutes of Health. Computing was supported by NWO through grant 2018/EW/ 00408559, BiG Grid, the Dutch e-Science Grid and SURFSARA.

\section{References}

Achenbach, T. M., Ivanova, M. Y., \& Rescorla, L. A. (2017). Empirically based

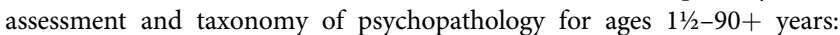
Developmental, multi-informant, and multicultural findings. Comprehensive Psychiatry, 79, 4-18.

Baaré, W. F., Hulshoff Pol, H. E., Boomsma, D. I., Posthuma, D., de Geus, E. J., Schnack, H. G., . . Kahn, R. S. (2001). Quantitative genetic modeling of variation in human brain morphology. Cerebral Cortex, 11, 816-824.

Bartels, M., Althoff, R. R., \& Boomsma, D. I. (2009). Anesthesia and cognitive performance in children: No evidence for a causal relationship. Twin Research and Human Genetics, 12, 246-253.

Bartels, M., Hendriks, A., Mauri, M., Krapohl, E., Whipp, A., Bolhuis, K., . Hagenbeek, F. (2018). Childhood aggression and the co-occurrence of behavioural and emotional problems: Results across ages 3-16 years from multiple raters in six cohorts in the EU-ACTION project. European Child \& Adolescent Psychiatry, 27, 1105-1121.

Bartels, M., Rietveld, M. J., Van Baal, G. C. M., \& Boomsma, D. I. (2002a). Genetic and environmental influences on the development of intelligence. Behavior Genetics, 32, 237-249.

Bartels, M., Rietveld, M. J., Van Baal, G. C. M., \& Boomsma, D. I. (2002b). Heritability of educational achievement in 12-year-olds and the overlap with cognitive ability. Twin Research and Human Genetics, 5, 544-553.

Bartels, M., van Beijsterveldt, C. T., Derks, E. M., Stroet, T. M., Polderman, T. J., Hudziak, J. J., \& Boomsma, D. I. (2007). Young Netherlands Twin Register (Y-NTR): A longitudinal multiple informant study of problem behavior. Twin Research and Human Genetics, 10, 3-11.

Bates, T. C., Maher, B. S., Medland, S. E., McAloney, K., Wright, M. J., Hansell, N. K., .. Gillespie, N. A. (2018). The nature of nurture: Using a virtual-parent design to test parenting effects on children's educational attainment in genotyped families. Twin Research and Human Genetics, 21, 73-83.

Boomsma, D., Beem, A., Van den Berg, M., Dolan, C., Koopmans, J., Vink, J., .. Slagboom, P. (2000). Netherlands Twin Family Study of Anxious Depression (NETSAD). Twin Research and Human Genetics, 3, 323-334.

Boomsma, D., De Geus, E., Vink, J., Stubbe, J., Distel, M., Hottenga, J., ... Bartels, M. (2006). Netherlands Twin Register: From twins to twin families. Twin Research and Human Genetics, 9, 849-857.

Boomsma, D., Helmer, Q., Nieuwboer, H., Hottenga, J., de Moor, M., van Den Berg, S., ... Dolan, C. (2018). An extended twin-pedigree study of neuroticism in the Netherlands Twin Register. Behavior Genetics, 48, 1-11.

Boomsma, D., Kempen, H., Leuven, J. G., Havekes, L., De Knijff, P., \& Frants, R. (1996). Genetic analysis of sex and generation differences in plasma lipid, lipoprotein, and apolipoprotein levels in adolescent twins and their parents. Genetic Epidemiology, 13, 49-60.

Boomsma, D., Orlebeke, J., \& Van Baal, G. (1992). The Dutch Twin Register: Growth data on weight and height. Behavior Genetics, 22, 247-251.

Boomsma, D., Vink, J. M., Van Beijsterveldt, T. C., de Geus, E. J., Beem, A. L., Mulder, E. J., ... Bartels, M. (2002). Netherlands Twin Register: A focus on longitudinal research. Twin Research and Human Genetics, 5, 401-406.

Boomsma, D., Willemsen, G., Vink, J. M., Bartels, M., Groot, P., Hottenga, J. J., ... Wertheim, R. (2008). Design and implementation of a twin-family database for behavior genetics and genomics studies. Twin Research and Human Genetics, 11, 342-348.

Bot, M., Middeldorp, C., De Geus, E., Lau, H., Sinke, M., Van Nieuwenhuizen, B., ... Penninx, B. (2017). Validity of LIDAS (LIfetime
Depression Assessment Self-report): A self-report online assessment of lifetime major depressive disorder. Psychological Medicine, 47, 279-289.

Bot, M., Vink, J. M., Willemsen, G., Smit, J. H., Neuteboom, J., Kluft, C., . . Penninx, B. W. (2013). Exposure to secondhand smoke and depression and anxiety: A report from two studies in the Netherlands. Journal of Psychosomatic Research, 75, 431-436.

Bouman, T. K., Luteijn, F., Albersnagel, F., \& Van der Ploeg, F. (1985). Enige ervaringen met de Beck depression inventory (BDI). Gedrag: tijdschrift voor psychologie.

Bovenberg, J., Kattenberg, M., Baselmans, B., Sinke, M., Hoekstra, R., Boomsma, D. I., \& Willemsen, G. (2016). Enhancing biobank participants' rights from paper to portal. Scripted, 13, 70.

Broer, L., Codd, V., Nyholt, D. R., Deelen, J., Mangino, M., Willemsen, G., . De Geus, E. J. (2013). Meta-analysis of telomere length in 19713 subjects reveals high heritability, stronger maternal inheritance and a paternal age effect. European Journal of Human Genetics, 21, 1163.

Cantril, H. (1965). Pattern of human concerns. New Brunswick, NJ: Rutgers University Press.

Conners, C., Erhardt, D., Epstein, J., Parker, J., Sitarenios, G., \& Sparrow, E. (1999). Self-ratings of ADHD symptoms in adults I: Factor structure and normative data. Journal of Attention Disorders, 3, 141-151.

Conners, C., Sitarenios, G., Parker, J. D., \& Epstein, J. N. (1998a). The revised Conners' Parent Rating Scale (CPRS-R): Factor structure, reliability, and criterion validity. Journal of Abnormal Child Psychology, 26, 257-268.

Conners, C., Sitarenios, G., Parker, J. D., \& Epstein, J. N. (1998b). Revision and restandardization of the Conners Teacher Rating Scale (CTRS-R): Factor structure, reliability, and criterion validity. Journal of Abnormal Child Psychology, 26, 279-291.

Costa, P., \& McCrae, R. (1989). NEO Five-Factor Inventory (NEO-FFI). Odessa, FL: Psychological Assessment Resources.

Davey Smith, G., \& Hemani, G. (2014). Mendelian randomization: Genetic anchors for causal inference in epidemiological studies. Human Molecular Genetics, 23, R89-R98.

de Geus, E. J., Posthuma, D., Kupper, N., van den Berg, M., Willemsen, G., Beem, A., ... Boomsma, D. (2005). A whole-genome scan for 24-hour respiration rate: A major locus at 10q26 influences respiration during sleep. The American Journal of Human Genetics, 76, 100-111.

de Geus, E. J., van't Ent, D., Wolfensberger, S. P., Heutink, P., Hoogendijk, W. J., Boomsma, D. I., \& Veltman, D. J. (2007). Intrapair differences in hippocampal volume in monozygotic twins discordant for the risk for anxiety and depression. Biological Psychiatry, 61, 1062-1071.

de Zeeuw, E. L., van Beijsterveldt, C. E., Glasner, T. J., de Geus, E. J., \& Boomsma, D. I. (2016). Arithmetic, reading and writing performance has a strong genetic component: A study in primary school children. Learning and Individual Differences, 47, 156-166.

de Zeeuw, E.L., Hottenga, J-J., Ouwens, K.G., Dolan, C.V., Ehli, E.A., Davies, G.E., Boomsma, D.I., \& van Bergen, E. (2019). Intergenerational transmission of education and ADHD: Effects of parental genotypes. BioRxiv. doi: https://doi.org/10.1101/664128.

den Braber, A., van't Ent, D., Blokland, G. A., van Grootheest, D. S., Cath, D. C., Veltman, D. J., \& Boomsma, D. I. (2008). An fMRI study in monozygotic twins discordant for obsessive-compulsive symptoms. Biological Psychology, 79, 91-102.

den Braber, A., van't Ent, D., Cath, D. C., Wagner, J., Boomsma, D. I., \& de Geus, E. J. (2010). Brain activation during cognitive planning in twins discordant or concordant for obsessive-compulsive symptoms. Brain, 133, 3123-3140.

den Braber, A., van't Ent, D., Stoffers, D., Linkenkaer-Hansen, K., Boomsma, D. I., ... de Geus, E. J. (2013). Sex differences in gray and white matter structure in age-matched unrelated males and females and opposite-sex siblings. International Journal of Psychological Research, 6, 7-21.

Derks, E. M., Hudziak, J. J., Dolan, C. V., van Beijsterveldt, T. C., Verhulst, F. C., \& Boomsma, D. I. (2008). Genetic and environmental influences on the relation between attention problems and attention deficit hyperactivity disorder. Behavior Genetics, 38, 11-23.

D’Onofrio, B. M., Turkheimer, E. N., Eaves, L.J., Corey, L.A., Berg, K., Solaas, M.H., \& Emery, R.E. (2003). The role of the Children of Twins 
design in elucidating causal relations between parent characteristics and child outcomes. Journal of Child Psychology and Psychiatry, 44, 1130-1144.

Doornweerd, S., De Geus, E. J., Barkhof, F., Van Bloemendaal, L., Boomsma, D. I., Van Dongen, J., . . IJzerman, R. G. (2018). Brain reward responses to food stimuli among female monozygotic twins discordant for BMI. Brain Imaging and Behavior, 12, 718-727.

Doornweerd, S., IJzerman, R. G., van der Eijk, L., Neter, J. E., van Dongen, J., van der Ploeg, H. P., \& de Geus, E. J. (2016). Physical activity and dietary intake in BMI discordant identical twins. Obesity, 24, 1349-1355.

Draisma, H. H., Beekman, M., Pool, R., van Ommen, G. J., Adamski, J., Prehn, C., ... Boomsma, D. I. (2013). Familial resemblance for serum metabolite concentrations. Twin Research and Human Genetics, 16, 948-961.

Ehli, E. A., Abdellaoui, A., Fedko, I. O., Grieser, C., Nohzadeh-Malakshah, S., Willemsen, G., . . . Hottenga, J. J. (2017). A method to customize population-specific arrays for genome-wide association testing. European Journal of Human Genetics, 25, 267.

Finnicum, C. T., Doornweerd, S., Dolan, C. V., Luningham, J. M., Beck, J. J., Willemsen, G., . . Davies, G. E. (2018). Metataxonomic analysis of individuals at BMI extremes and monozygotic twins discordant for BMI. Twin Research and Human Genetics, 21, 203-213.

Goodman, R. (1997). The Strengths and Difficulties Questionnaire: A research note. Journal of Child Psychology and Psychiatry, 38, 581-586.

Gresham, F. M., \& Elliott, S. N. (1990). Social Skills Rating System: Manual. Circle Pines, MN: American Guidance Service.

Groot, A. S., de Sonneville, L. M., Stins, J. F., \& Boomsma, D. I. (2004). Familial influences on sustained attention and inhibition in preschoolers. Journal of Child Psychology and Psychiatry, 45, 306-314.

Hagenbeek, F. A., Pool, R., Van Dongen, J., Draisma, H. H., Hottenga, J. J., Willemsen, G., ... Boomsma, D. I. (2019). The genomic architecture of blood metabolites based on a decade of genome-wide analyses. bioRxiv. doi:10.1101/661769

Hendriks, A. M., Ip, H. F., Nivard, M. G., Finkenauer, C., Van Beijsterveldt, C. E. M., Bartels, M., \& Boomsma, D. I. (2019). Content, diagnostic, correlational, and genetic similarities between common measures of childhood aggressive behaviors and related psychiatric traits. Manuscript submitted for publication.

Hoekstra, R. A., Bartels, M., \& Boomsma, D. I. (2007). Longitudinal genetic study of verbal and nonverbal IQ from early childhood to young adulthood. Learning and Individual Differences, 17, 97-114.

Hoekstra, C., Meijer, P., Kluft, C., Heutink, P., Smit, G., de Geus, E., ... Boomsma, D. I. (2004). Genetics of dizygotic twinning: A feasibility study for a biobank. Twin Research and Human Genetics, 7, 556-563.

Hoekstra, C., Willemsen, G., van Beijsterveldt, C. T., Lambalk, C. B., Montgomery, G. W., \& Boomsma, D. I. (2010). Body composition, smoking, and spontaneous dizygotic twinning. Fertility and Sterility, 93, 885-893.

Hoekstra, C., Willemsen, G., van Beijsterveldt, T. C., Montgomery, G. W., \& Boomsma, D. I. (2008). Familial twinning and fertility in Dutch mothers of twins. American Journal of Medical Genetics Part A, 146, 3147-3156.

Huguet, P., Carlier, M., Dolan, C. V., de Geus, E. J., \& Boomsma, D. I. (2017). Social comparison orientation in monozygotic and dizygotic twins. Twin Research and Human Genetics, 20, 550-557.

Jansen, R., Batista, S., Brooks, A. I., Tischfield, J. A., Willemsen, G., Van Grootheest, G., ... Madar, V. (2014). Sex differences in the human peripheral blood transcriptome. BMC Genomics, 15, 33.

Kempen, H., De Knijff, P., Boomsma, D., Van Der Voort, H., Leuven, J. G., \& Havekes, L. (1991). Plasma levels of lathosterol and phytosterols in relation to age, sex, anthropometric parameters, plasma lipids, and apolipoprotein $\mathrm{E}$ phenotype, in 160 Dutch families. Metabolism, 40, 604-611.

Kong, A., Thorleifsson, G., Frigge, M. L., Vilhjalmsson, B. J., Young, A. I., Thorgeirsson, T. E., ... Masson, G. (2018). The nature of nurture: Effects of parental genotypes. Science, 359, 424-428.

Konijnenberg, E., Carter, S. F., Ten Kate, M., den Braber, A., Tomassen, J., Amadi, C., .. . Visser, P. J. (2018). The EMIF-AD PreclinAD study: Study design and baseline cohort overview. Alzheimer's Research \& Therapy, 10, 75. doi:10.1186/s13195-018-0406-7

Kupper, N. H., Willemsen, G., van den Berg, M., de Boer, D., Posthuma, D., Boomsma, D. I., \& de Geus, E. J. (2004). Heritability of ambulatory heart rate variability. Circulation, 110, 2792-2796.
Lamb, D. J., Vink, J. M., Middeldorp, C. M., van Beijsterveldt, C. E., Haak, M. C., Overbeek, L. I., \& Boomsma, D. I. (2012). Effects of chorionicity and zygosity on triplet birth weight. Twin Research and Human Genetics, 15, 149-157.

Langendonk, J. M., Van Beijsterveldt, C., Brouwer, S. I., Stroet, T., Hudziak, J. J., \& Boomsma, D. I. (2007). Assessment of motor milestones in twins. Twin Research and Human Genetics, 10, 835-839.

Larson, T., Anckarsäter, H., Gillberg, C., Ståhlberg, O., Carlström, E., Kadesjö, B., ... Gillberg, C. (2010). The autism-tics, AD/HD and other comorbidities inventory (A-TAC): Further validation of a telephone interview for epidemiological research. BMC Psychiatry, 10, 1.

Lin, B. D., Carnero-Montoro, E., Bell, J. T., Boomsma, D. I., de Geus, E. J., Jansen, R., ... Hottenga, J. J. (2017). 2SNP heritability and effects of genetic variants for neutrophil-to-lymphocyte and platelet-to-lymphocyte ratio. Journal of Human Genetics, 62, 979-988.

Luningham, J. M., McArtor, D. B., Bartels, M., Boomsma, D. I., \& Lubke, G. H. (2017). Sum scores in twin growth curve models: Practicality versus bias. Behavior Genetics, 47, 516-536.

Mbarek, H., Steinberg, S., Nyholt, D. R., Gordon, S. D., Miller, M. B., McRae, A. F., ... De Geus, E. J. (2016). Identification of common genetic variants influencing spontaneous dizygotic twinning and female fertility. The American Journal of Human Genetics, 98, 898-908.

Meulemans, W. J., Lewis, C. M., Boomsma, D. I., Derom, C. A., Van den Berghe, H., Orlebeke, J. F., ... Derom, R. M. (1996). Genetic modelling of dizygotic twinning in pedigrees of spontaneous dizygotic twins. American Journal of Medical Genetics, 61, 258-263.

Meulenbelt, I., Droog, S., Trommelen, G., Boomsma, D. I., \& Slagboom, P. E. (1995). High-yield noninvasive human genomic DNA isolation method for genetic studies in geographically dispersed families and populations. American Journal of Human Genetics, 57, 1252.

Middeldorp, C. M., Birley, A. J., Cath, D. C., Gillespie, N. A., Willemsen, G., Statham, D. J., . . Beem, A. L. (2005). Familial clustering of major depression and anxiety disorders in Australian and Dutch twins and siblings. Twin Research and Human Genetics, 8, 609-615.

Middeldorp, C. M., de Geus, E. J., Beem, A. L., Lakenberg, N., Hottenga, J.-J., Slagboom, P. E., \& Boomsma, D. I. (2007). Family based association analyses between the serotonin transporter gene polymorphism (5-HTTLPR) and neuroticism, anxiety and depression. Behavior Genetics, 37, 294-301.

Min, J. L., Lakenberg, N., Bakker-Verweij, M., Suchiman, E., Boomsma, D. I., Slagboom, P. E., \& Meulenbelt, I. (2006). High microsatellite and SNP genotyping success rates established in a large number of genomic DNA samples extracted from mouth swabs and genotypes. Twin Research and Human Genetics, 9, 501-506.

Minica, C. C., Dolan, C. V., Boomsma, D. I., de Geus, E., \& Neale, M. C. (2018). Extending Causality Tests with genetic instruments: An integration of Mendelian randomization with the classical twin design. Behavior Genetics, 48, 337-349.

Morey, L. C. (2003). Essentials of PAI assessment (vol. 29). Hoboken, NJ: Wiley.

Neijts, M., van Lien, R., Kupper, N., Boomsma, D., Willemsen, G., \& de Geus, E. J. (2015). Heritability and temporal stability of ambulatory autonomic stress reactivity in unstructured 24-hour recordings. Psychosomatic Medicine, 77, 870-881.

Painter, J. N., Willemsen, G., Nyholt, D., Hoekstra, C., Duffy, D. L., Henders, A. K., ... Skolnick, M. (2010). A genome wide linkage scan for dizygotic twinning in 525 families of mothers of dizygotic twins. Human Reproduction, 25, 1569-1580.

Palmer, T. M., Sterne, J. A., Harbord, R. M., Lawlor, D. A., Sheehan, N. A., Meng, S., . . . Didelez, V. (2011). Instrumental variable estimation of causal risk ratios and causal odds ratios in Mendelian randomization analyses. American Journal of Epidemiology, 173, 1392-1403.

Pickrell, J. K., Berisa, T., Liu, J. Z., Segurel, L., Tung, J. Y., \& Hinds, D. A. (2016). Detection and interpretation of shared genetic influences on 42 human traits. Nature Genetics, 48, 709-717.

Pierce, B. L., Ahsan, H., \& VanderWeele, T. J. (2010). Power and instrument strength requirements for Mendelian randomization studies using multiple genetic variants. International Journal of Epidemiology, 40, 740-752.

Polderman, T. J., Gosso, M., Posthuma, D., van Beijsterveldt, C. E., Heutink, P., Verhuls, F. C., \& Boomsma, D. I. (2006a). A longitudinal twin study on 
IQ, executive functioning, and attention problems during childhood and early adolescence. Acta Neurologica Belgica, 106, 191-207.

Polderman, T. J., Posthuma, D., De Sonneville, L. M., Verhulst, F. C., \& Boomsma, D. I. (2006b). Genetic analyses of teacher ratings of problem behavior in 5-year-old twins. Twin Research and Human Genetics, 9, 122-130.

Posthuma, D., de Geus, E. J., Mulder, E. J., Smit, D. J., Boomsma, D. I., \& Stam, C. J. (2005). Genetic components of functional connectivity in the brain: The heritability of synchronization likelihood. Human Brain Mapping, 26, 191-198.

Rietveld, M., Dolan, C., Van Baal, G., \& Boomsma, D. (2003). A twin study of differentiation of cognitive abilities in childhood. Behavior Genetics, 33, 367-381.

Rietveld, M., van Der Valk, J., Bongers, I., Stroet, T., Slagboom, P., \& Boomsma, D. (2000). Zygosity diagnosis in young twins by parental report. Twin Research, 3, 134-141.

Rothbart, M. K., Ahadi, S. A., Hershey, K. L., \& Fisher, P. (2001). Investigations of temperament at three to seven years: The Children's Behavior Questionnaire. Child Development, 72, 1394-1408.

Schutte, N. M., Huppertz, C., Doornweerd, S., Bartels, M., de Geus, E. J., \& van der Ploeg, H. P. (2019). Heritability of objectively assessed and selfreported sedentary behavior. Manuscript submitted for publication.

Schutte, N. M., Nederend, I., Hudziak, J. J., Bartels, M., \& de Geus, E. J. (2016). Twin-sibling study and meta-analysis on the heritability of maximal oxygen consumption. Physiological Genomics, 48, 210-219.

Simonis-Bik, A. M., Eekhoff, E. M., Diamant, M., Boomsma, D. I., Heine, R. J., Dekker, J. M., ... de Geus, E. J. (2008). The heritability of HbA1c and fasting blood glucose in different measurement settings. Twin Research and Human Genetics, 11, 597-602.

Sirota, M., Willemsen, G., Sundar, P., Pitts, S. J., Potluri, S., Prifti, E., . . Boomsma, D. I. (2015). Effect of genome and environment on metabolic and inflammatory profiles. PLoS One, 10, e0120898.

Snieder, H., Van Doornen, L., \& Boomsma, D. I. (1997). The age dependency of gene expression for plasma lipids, lipoproteins, and apolipoproteins. American Journal of Human Genetics, 60, 638.

Swagerman, S. C., de Geus, E. J., Kan, K.-J., van Bergen, E., Nieuwboer, H. A., Koenis, M. M., . . G Gur, R. C. (2016). The computerized neurocognitive battery: Validation, aging effects, and heritability across cognitive domains. Neuropsychology, 30, 53.

Teeuw, J., Brouwer, R. M., Koenis, M. M., Swagerman, S. C., Boomsma, D. I., \& Hulshoff Pol, H. E. (2019). Genetic influences on the development of cerebral cortical thickness during childhood and adolescence in a Dutch longitudinal twin sample: The brainscale study. Cerebral Cortex, 29, 0-15.

van Baal, G. C. M., de Geus, E. J., \& Boomsma, D. I. (1998). Longitudinal study of genetic influences on ERP-P3 during childhood. Developmental Neuropsychology, 14, 19-45.

van Beek, J. H., Lubke, G. H., de Moor, M. H., Willemsen, G., de Geus, E. J., Hottenga, J. J., . . Boomsma, D. I. (2015). Heritability of liver enzyme levels estimated from genome-wide SNP data. European Journal of Human Genetics, 23, 1223.

van Beijsterveldt, C., Groen-Blokhuis, M., Hottenga, J. J., Franić, S., Hudziak, J. J., Lamb, D., ... Schutte, N. (2013). The Young Netherlands Twin Register (YNTR): Longitudinal twin and family studies in over 70,000 children. Twin Research and Human Genetics, 16, 252-267.

van Beijsterveldt, C., Molenaar, P., de Geus, E., \& Boomsma, D. (1996). Heritability of human brain functioning as assessed by electroencephalography. American Journal of Human Genetics, 58, 562.

van Beijsterveldt, C., Overbeek, L., Rozendaal, L., McMaster, M., Glasner, T., Bartels, M., ... Boomsma, D. (2016). Chorionicity and heritability estimates from twin studies: The prenatal environment of twins and their resemblance across a large number of traits. Behavior Genetics, 46, 304-314.

van Bergen, E., Snowling, M. J., de Zeeuw, E. L., van Beijsterveldt, C. E., Dolan, C. V., \& Boomsma, D. I. (2018). Why do children read more? The influence of reading ability on voluntary reading practices. Journal of Child Psychology and Psychiatry, 59, 1205-1214.

van Den Berg, S. M., De Moor, M. H., McGue, M., Pettersson, E., Terracciano, A., Verweij, K. J., ... Van Grootheest, G. (2014). Harmonization of neuroticism and extraversion phenotypes across inventories and cohorts in the Genetics of Personality Consortium: An application of item response theory. Behavior Genetics, 44, 295-313.

van Dongen, J., Nivard, M. G., Willemsen, G., Hottenga, J. J., Helmer, Q., Dolan, C. V., ... Boomsma, D. I. (2016). Genetic and environmental influences interact with age and sex in shaping the human methylome. Nature Communications, 7, 11115.

van Dongen, J., Willemsen, G., Heijmans, B. T., Neuteboom, J., Kluft, C., Jansen, R., . . Boomsma, D. I. (2015). Longitudinal weight differences, gene expression and blood biomarkers in BMI-discordant identical twins. International Journal of Obesity, 39, 899.

van Leeuwen, M., van Den Berg, S. M., \& Boomsma, D. I. (2008). A twin-family study of general IQ. Learning and Individual Differences, 18, 76-88.

van Leeuwen, M., van den Berg, S. M., Peper, J. S., Pol, H. E. H., \& Boomsma, D. I. (2009). Genetic covariance structure of reading, intelligence and memory in children. Behavior Genetics, 39, 245-254.

van Soelen, I. L., Brouwer, R. M., Peper, J. S., van Beijsterveldt, T. C., van Leeuwen, M., de Vries, L. S., .. B Boomsma, D. I. (2010). Effects of gestational age and birth weight on brain volumes in healthy 9 year-old children. The Journal of Pediatrics, 156, 896-901.

van Soelen, I. L., Brouwer, R. M., Peper, J. S., van Leeuwen, M., Koenis, M. M., van Beijsterveldt, T. C., ... Boomsma, D. I. (2012). Brain SCALE: Brain structure and cognition: An adolescent longitudinal twin study into the genetic etiology of individual differences. Twin Research and Human Genetics, 15, 453-467.

van't Ent, D., Lehn, H., Derks, E., Hudziak, J., Van Strien, N., Veltman, D., . . Boomsma, D. (2007). A structural MRI study in monozygotic twins concordant or discordant for attention/hyperactivity problems: Evidence for genetic and environmental heterogeneity in the developing brain. Neuroimage, 35, 1004-1020.

van't Ent, D., Van Beijsterveldt, C., Derks, E., Hudziak, J., Veltman, D., Todd, R., ... De Geus, E. (2009). Neuroimaging of response interference in twins concordant or discordant for inattention and hyperactivity symptoms. Neuroscience, 164, 16-29.

van't Ent, D., van Soelen, I. L., Stam, K. J., de Geus, E. J., \& Boomsma, D. I. (2010). Genetic influence demonstrated for MEG-recorded somatosensory evoked responses. Psychophysiology, 47, 1040-1046.

Vink, J. M., Van Kemenade, F. J., Meijer, C. J., Casparie, M. K., Meijer, G. A., \& Boomsma, D. I. (2011). Cervix smear abnormalities: Linking pathology data in female twins, their mothers and sisters. European Journal of Human Genetics, 19, 108.

Willemsen, G., De Geus, E. J., Bartels, M., van Beijsterveldt, C. T., Brooks, A. I., Estourgie-van Burk, G. F., ... Kluft, K. (2010). The Netherlands Twin Register biobank: A resource for genetic epidemiological studies. Twin Research and Human Genetics, 13, 231-245.

Willemsen, G., Vink, J. M., Abdellaoui, A., den Braber, A., van Beek, J. H., Draisma, H. H., ... van Lien, R. (2013). The Adult Netherlands Twin Register: Twenty-five years of survey and biological data collection. Twin Research and Human Genetics, 16, 271-281.

Wittchen, H. U. (1994). Reliability and validity studies of the WHO-Composite International Diagnostic Interview (CIDI): A critical review. Journal of Psychiatric Research, 28, 57-84.

Wright, F. A., Sullivan, P. F., Brooks, A. I., Zou, F., Sun, W., Xia, K., . . . Boomsma, D. I. (2014). Heritability and genomics of gene expression in peripheral blood. Nature Genetics, 46, 430-437.

Wu, T., Boezen, H., Postma, D., Los, H., Postmus, P., Snieder, H., \& Boomsma, D. (2010). Genetic and environmental influences on objective intermediate asthma phenotypes in Dutch twins. European Respiratory Journal, 36, 261-268.

\section{Appendix. Zygosity}

\section{Methods}

To determine the accuracy of zygosity determination in children aged $0-16$ years, the agreement between zygosity based on a blood group or DNA tests and zygosity based on discriminant analysis of survey items on resemblance was investigated. In earlier research, prediction accuracy of zygosity was around $93 \%$ in children 
Table A1. Zygosity prediction accuracy of YNTR questionnaire items compared to DNA

\begin{tabular}{lc}
\hline YNTR questionnaire & Correctly classified (\%) \\
\hline Overall (multiple questionnaires) & 96.8 \\
\hline Age 1 & 78.9 \\
\hline Age 2 & 93.8 \\
\hline Age 3 mother & 94.9 \\
\hline Age 3 father & 94.1 \\
\hline Age 5 mother & 97.5 \\
\hline Age 7 mother & 95.9 \\
\hline Age 7 father & 96.5 \\
\hline Age 10 mother & 96.1 \\
\hline Age 10 father & 96.3 \\
\hline Age 12 mother & 96.6 \\
\hline Age 12 father & 95.9 \\
\hline Age 14 self & 91.8 \\
\hline Age 16 self & 94.9 \\
\hline
\end{tabular}

(Rietveld et al., 2000). Since then, an additional item was added to the NTR questionnaires and substantially more DNA data have become available. We reevaluated zygosity assignments, based on surveys obtained at ages $3,5,7,10,12,14$ and 16 years. These contain 10 zygosity items about resemblance between the twins (6 items about physical similarities and 4 items about confusion by parents and others). At ages 3-12 years, mothers and fathers and at ages 14-16 years the twins themselves filled out the questions. In adults aged 18-99 years, multiple surveys contain eight zygosity items (five items about resemblance and three items about confusion by parents and others). Here, the questions were answered by the twins.

Because knowledge of the result of a zygosity test may affect responses, we only included data from same-sex twins whose survey information had been completed before they, or their parents, received the results of the DNA tests. For the children, this resulted in a sample of 5776 twins and for adults in a sample of 3512 twins.

For children, the data were randomly divided into a training set (60\%) and a testing set (40\%). In the training set, linear discriminant analysis was applied to survey data from each informant (mother, father and self) and ages 3-16 years. Linear discriminant analysis determines the axes that maximize the separation of different classes, in our case MZ and DZ. This analysis generated a linear function of the weighted sum of the items, in which the weights were optimized to distinguish between $\mathrm{MZ}$ and DZ twin-pairs. The outcomes then were applied to the data from the testing set $(N=2260)$. If multiple surveys were available (either multiple ages, multiple informants or both), the most frequently predicted zygosity was chosen as the assigned zygosity. If an equal number of $\mathrm{MZ}$ and DZ outcomes was observed, the mean probability of being MZ determined by the discriminant analyses was used (MZ: probability $>.5$ and DZ: probability $<.5$ ). To determine the accuracy of our zygosity classification by the questionnaire items, we determined the proportion in which the true zygosity and the assigned zygosity corresponded. If there was no childhood survey after age 2 years, the item about resemblance from the questionnaire collected at age 2 years was used (MZ: 'yes, but barely different' or 'yes, but well distinguishable' and DZ: 'no, not a lot' or 'no, not at all'). If there also was no information at age 2 years, the item from the questionnaire at age 1 year was used (MZ: 'MZ twins' and DZ: 'DZ twins').
Table A2. Ranks for the predictive value of the zygosity items in YNTR and ANTR surveys

\begin{tabular}{|c|c|c|c|c|c|c|}
\hline Item & $\begin{array}{l}\text { Age } 3 \\
\text { mother- } \\
\text { rated }\end{array}$ & $\begin{array}{l}\text { Age } 3 \\
\text { father- } \\
\text { rated }\end{array}$ & $\begin{array}{l}\text { Age } 12 \\
\text { mother- } \\
\text { rated }\end{array}$ & $\begin{array}{l}\text { Age } 12 \\
\text { father- } \\
\text { rated }\end{array}$ & $\begin{array}{l}\text { Age } 16 \\
\text { self- } \\
\text { rated }\end{array}$ & $\begin{array}{l}\text { Adults } \\
\text { self- } \\
\text { rated }\end{array}$ \\
\hline $\begin{array}{l}\text { Facial } \\
\text { appearance }\end{array}$ & 7 & 3 & 6 & 5 & 5 & 7 \\
\hline Hair color & 3 & 8 & 5 & 4 & 4 & 5 \\
\hline Face color & 4 & 6 & 4 & 6 & 7 & 6 \\
\hline Eye color & 5 & 4 & 7 & 7 & 2 & 4 \\
\hline Hair structure & 2 & 2 & 3 & 3 & 3 & - \\
\hline Spitting image & 10 & 9 & 9 & 9 & 1 & 1 \\
\hline $\begin{array}{l}\text { Confusion by } \\
\text { mom/dad }\end{array}$ & 8 & 5 & 10 & 8 & 6 & 8 \\
\hline $\begin{array}{l}\text { Confusion by } \\
\text { other family } \\
\text { members }\end{array}$ & 1 & 1 & 2 & 2 & 8 & 3 \\
\hline $\begin{array}{l}\text { Confusion by } \\
\text { strangers }\end{array}$ & 6 & 7 & 1 & 1 & 9 & 2 \\
\hline $\begin{array}{l}\text { Confusion on } \\
\text { photos }\end{array}$ & 9 & 10 & 8 & 10 & - & - \\
\hline
\end{tabular}

YNTR $=$ Young Netherlands Twin Register; ANTR $=$ Adult Netherlands Twin Register Note: $1=$ most predictive item; $10=$ least predictive item.

For adults a similar scheme was used: $60 \%$ of the data were randomly assigned to be in the training set and $40 \%$ to be in the testing set. The first available survey with zygosity items was analyzed. The outcomes of the linear discriminant analysis of the training set were used to predict zygosity in the testing set $(N=1362)$.

\section{Results}

In children, results indicate that the entire procedure of zygosity prediction by the 10 -item zygosity questionnaires correctly classified zygosity in $96.8 \%$. Prediction accuracy for all YNTR questionnaires separately can be found in Table A1. For $95.8 \%$ of this sample, data on the 10-item zygosity list included in the questionnaires at ages 3-16 years were available. If only these participants were considered, the accuracy of zygosity classification was $97.2 \%$. In the remaining sample, only surveys at earlier ages, when twins are 1 and 2 years, were available. These were completed by mothers and included one question at age 1 year ('According to you, the twins are', with answer options 'DZ twins' and 'MZ twins') and one question at age 2 years ('Do the children resemble each other' - with answer options 'yes, they are barely different', 'yes, but well distinguishable', 'no, not a lot' and 'no, not at all'). If only the questionnaire at age 2 years is used, zygosity prediction is accurate in $93.8 \%$ of the cases. When only the questionnaire at age 1 year is used, prediction accuracy of zygosity drops to $78.9 \%$. Participants with data at age 1 or 2 years only are underrepresented in the sample, $(N=96)$.

In adults, zygosity prediction based on survey items was accurate in $95.9 \%$. In Table A2, the results of the linear discriminant analysis are displayed. In adults, the item that distinguishes best between MZ and DZ twins was 'Were you each other's spitting image as children?', whereas the item 'Did mother and father mix you up when you were young' does not distinguish well. In parent-reports on children, confusion by other family members than parents was a well-distinguishing item. 